\title{
Manuscript to Print and Print to Print: On the Transmission History of Jacob ben Asher's Tur Orah Hayyim
}

\author{
Nadia Vidro \\ University College London
}

\begin{abstract}
This article is a case study in the transition of texts from manuscript to print. It looks at all surviving manuscripts and 15th-16th-centuries printed editions of Jacob ben Asher's 'Arba'ah Turim, Tur Orah Hayyim. Based on a close textual investigation of Tur Orah Hayyim, chapter 428, it identifies and dates manuscript clusters, and establishes how different imprints are linked with the manuscript tradition and with each other. The article suggests that the Soncino 1490 imprint by Solomon Soncino exerted a crucial influence on the printed text of Tur Orah Hayyim. Whereas before imprints were independent and closely associated with individual manuscripts, Soncino 1490

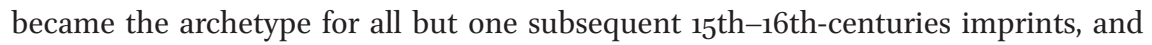
direct dependence on manuscripts subsided.
\end{abstract}

\section{Keywords}

Jacob ben Asher - 'Arba'ah Turim, Tur Orah Hayyim - Soncino - printing - manuscripts textual transmission - calendar

This article is a case study in the transition of texts from manuscript to print. It looks at Tur Orah Hayyim, the first part of the influential 14th-century legal

* This article was researched and written as part of the ERC Advanced Grant project 'Calendars in Late Antiquity and the Middle Ages: Standardization and Fixation', at UCL. I thank Prof Sacha Stern (UCL) and the anonymous Zutot reviewers for their valuable comments and suggestions.

(C) NADIA VIDRO, 2017 | DOI:10.1163/18750214-12151074

This is an open access article distributed under the terms of the prevailing CC-BY-NC License 
code 'Arba'ah Turim (The Four Pillars) composed in Toledo by the eminent halakhist of Ashkenazi origins, Jacob ben Asher (Cologne, c. 1270 - Toledo, c. 1340). ' 'Arba'ah Turim was a widely used and authoritative work in Sepharad and Ashkenaz alike, and became a corner-stone of much subsequent halakhic writing, including Joseph Caro's Shulhan Arukh.

Tur Orah Hayyim (The Way of Life, henceforth тон), is dedicated to laws of prayer, blessings, Sabbath and festivals. It is preserved in around 60 manuscripts and was printed over 20 times in the course of the 15th and 16th centuries. The manuscript transmission of тон has been studied by Judah Galinsky, who identifies two recensions of the work, both attested in all geo-cultural areas. $^{2}$ The original short recension is closer, both stylistically and halakhically, to Jacob ben Asher's earlier works and to opinions of his famous father Asher ben Yehiel, but is less clearly formulated and has more difficult readings. The second, extended recension shows more independence from earlier works and introduces clarifications of wording and explanations of halakha. Most manuscripts of тон do not consistently represent either recension but contain a mixed version of the text, following the short recension in some places and the extended recension in others, or mixing the two versions. ${ }^{3}$ Galinsky's conclusions are based on a macro-analysis of the entire book and do not take into account textual variants on the level of single words.

The transmission of тон in print is virtually unstudied. Galinsky incorporated three incunabula into his corpus (Piove $1475^{4}$ and Hij 1485 representing the original recension, and Sp 1490 representing the extended recension) and included a brief section on the Warsaw 1882 imprint. Other studies in the history of printing 'Arba'ah Turim do not pay attention to the formation and transmission of the text itself but rely on similarities between printers' materials, such as types and decorative borders, as well as printers' introductions and

1 On Jacob ben Asher and his work 'Arba'ah Turim see Y.D. Galinsky, 'The Four Turim and the Halakhic Literature of 14th Century Spain: Historical, Literary and Halakhic Aspects' (Hebrew) (PhD diss., Bar Ilan University 1999); for more references see E. Kupfer and

D. Derovan, 'Jacob ben Asher,' in Encyclopaedia Judaica 11:30-31. Gale Virtual Reference Library, go.galegroup.com/ps/i.do?p=GVRL\&sw=w\&u=cambuni\&v=2.1\&id=GALE\%7CCX2 $587509846 \&$ it=r\&asid=40828fd2a 4 cd $159 d_{7} 6 a_{30536 a c o e 2 o b 7}$ (accessed November 30, 2016).

2 Galinsky, 'The Four Turim,' 309-335.

3 Galinsky, 'The Four Turim,' 310-311.

4 For sigla see Appendix 1. 
included commentaries in order to establish relationships between various imprints. $^{5}$

The purpose of this article is to study textual relationships between manuscripts and printed editions of тон and to establish how different imprints are linked with the manuscript tradition and with each other. Identifying these links will help trace the formation of the printed тон and estimate its proximity to the authorial text. It will also contribute to our understanding of early modern practices in publishing texts composed before the age of printing by addressing such questions as: Did printers work with manuscript copies or with earlier imprints? Did they reproduce individual manuscripts or create printer's copies by collating various manuscripts? On the other hand, the article does not look at the influence of printed тон on manuscripts copied after print for the simple reason that very few such manuscripts survive, suggesting that few may have been produced. ${ }^{6}$

Methodologically, my analysis differs both from Galinsky's macro-analysis of entire manuscripts and from studies of paratextual elements in printed editions. It is based on a close investigation of a sample text taken from тон, chapter $428^{7}$ paying attention to textual differences on the level of short phrases, single words and morphological and syntactical elements. The corpus for my analysis is made of all known pre-modern manuscripts ${ }^{8}$ and $15^{\text {th- }}$ and

5 On printed editions of 'Arba'ah Turim see Bibliography of the Hebrew Book 1470-1960 (http:// web.nli.org.il/sites/NLI/English/infochannels/Catalogs/bibliographic-databases/Pages/ the-hebrew-book.aspx, accessed December 1, 2016); British Library Incunabula Short Title Catalogue (http://istc.bl.uk/search/search.html?operation=record\&rsid=361144\&q=0; accessed December 1, 2016); Gesamtkatalog der Wiegendrücke (http://www.gesamtkatalogderwiegendrucke.de; accessed December 1, 2016); Y. Vinograd, Thesaurus of the Hebrew Book (Hebrew) (Jerusalem 1993); M.J. Heller, The Sixteenth Century Hebrew Book. An Abridged Thesaurus (Leiden 2004); A.K. Offenberg, 'The Printing History of the Constantinople Hebrew Incunable of 1493: a Mediterranean Voyage of Discovery,' British Library Journal 22 (1996) 221-235.

6 See footnote 8 .

7 This chapter number is correct for most printed editions (see below). The numeration of chapters in manuscripts is unstable and is not always present (see Galinsky, 'The Four Turim,' 321 and nn. $51^{-52}$ there).

8 According to the Merhav catalogue of the National Library of Israel, the vast majority of тон manuscripts were copied before the 16th century. The few surviving manuscripts of тон dated in the catalogue to the 16 th and 17 th centuries are incomplete and do not preserve the text under consideration. The only manuscript dated in Merhav to the 18th century - SPB 211 - is, in fact, a 15th-century copy (see Appendix 1). Only two 19th-century manuscripts of тон are recorded, both in a Yemenite hand: Ottawa, National Library of 
16th-centuries printed editions that contain this chapter (I looked at one, sometimes two copies of each imprint). A list of analysed sources is given in Appendix 1. Because the studied portion of the text is small, all reached conclusions are provisional and require confirmation from the analysis of other passages. A number of observations on passages external to the studied chapter are used to support the results.

тон, chapter 428 belongs to the book's calendar section and contains calendar reckoning rules, as well as two calendar tables and their description. It is mainly the description of tables that is analysed here. Although this choice was originally conditioned by my interest in the history of calendar tables in тон,${ }^{9}$ this sample text has a number of advantages. Its transmission is relatively uniform without significant additions or deletions and as such allows carrying out a micro-analysis without having to take into consideration any major recensional developments. Being part of the calendar section and associated with calendar tables the sample allows making some chronological observations. Furthermore, chapter 428 is one of the very few chapters preserved in the earliest surviving witness of тон, a miscellany copied in 1380 (NY 527).

\section{Calendar Tables in тон, Chapter 428}

тон, chapter 428 includes two calendar tables and their description. The first table is a pre-calculated calendar said to cover the period $5055^{-6000 ~ A M}$ $\left(1294 / 5^{-2239 / 40}\right)$. The second table contains information on the arrangement of months, festivals, fasts and biblical pericopes in Jewish years of different types. Together the two tables give a reader all required information on any year of his interest. In the prose text Jacob ben Asher describes the structure and contents of the pre-calculated calendar and explains the short-hand

Canada, Saul Hayes Collection 74 and University of Toronto 5302. I was unable to check these manuscripts.

9 See N. Vidro, 'Calendar Tables in Manuscript and Printed 'Arba'ah Turim: Tur Orah Hayyim, Chapter 428,' Journal of Jewish Studies 69(1) (Spring 2018) 58-85. The main objective of this article is to identify, among many different attested calendars, the original calendar table included by Jacob ben Asher, to determine its sources and to follow its transmission and evolution in manuscripts and printed editions of тон. Although I divide attested tables into families, these results are not directly relevant for the transition of тон from manuscript to print because calendar tables in printed editions of тон appear relatively late and are not based on those found in manuscripts. 
notation employed therein. He then teaches readers how to use the tables, addressing audiences that have some understanding of how to handle a calendar table as well as those who have no calendar knowledge at all other than the date from Creation.

\section{Analysis of the Manuscript Corpus}

As a pre-requisite to understanding the manuscript to print transition of $\mathrm{TOH}$, a textual study of the manuscript corpus was performed by collating surviving manuscript witnesses of the description of calendar tables in тон, chapter 428 . Data generated by the collation were analysed manually as well as with NeighborNet, a computerized method for creating networks from data sequences. Clustering textual witnesses with NeighborNet is discussed in Appendix 2. NeighborNet graphs included in this article do not represent stemmatic relationships, but simply put witnesses with similar readings closer together, i.e. visualize the structure of the corpus without claiming that certain copies are closer to the original or indicating lines of descent between manuscripts.

A clustering of all manuscripts that contain the description of tables in chapter 428 (Fig. 1) shows that the corpus of тоH manuscripts does not neatly divide into separate branches. This is a reflection of the fact that most manuscripts carry a mixed version of the text and were copied from multiple exemplars or an exemplar glossed with alternative readings as a result of an earlier collation. ${ }^{10}$ Nonetheless, a number of clusters can be identified, three of which are important for the study of the transmission of тон from manuscript to print (colour-coded in red, blue and green in Fig. 1). These clusters are stably present for different data sub-sets and are supported by Galinsky's earlier findings.

10 Galinsky, 'The Four Turim,' $310-311$. Such editorial activity of scholar-scribes is a common feature in the transmission of Jewish texts, see M. Beit-Arie, 'Publication and Reproduction of Literary Texts in Jewish Medieval Civilization: Jewish Scribality and its Impact on the Texts Transmitted,' in Y. Elman and I. Gershoni, eds., Transmitting Jewish Traditions: Orality, Textuality, and Cultural Diffusion (New Haven 2000) 225-247. For alternative copying practices and evidence of communally organized Hebrew manuscript copying in medieval Italy, see I.M. Sandman, 'The Transmission of Sephardic Scientific Works in Italy, in Y.Tz. Langermann and R. Morrison, eds., Texts in Transit in the Medieval Mediterranean (University Park, PA 2016) 198-221. 


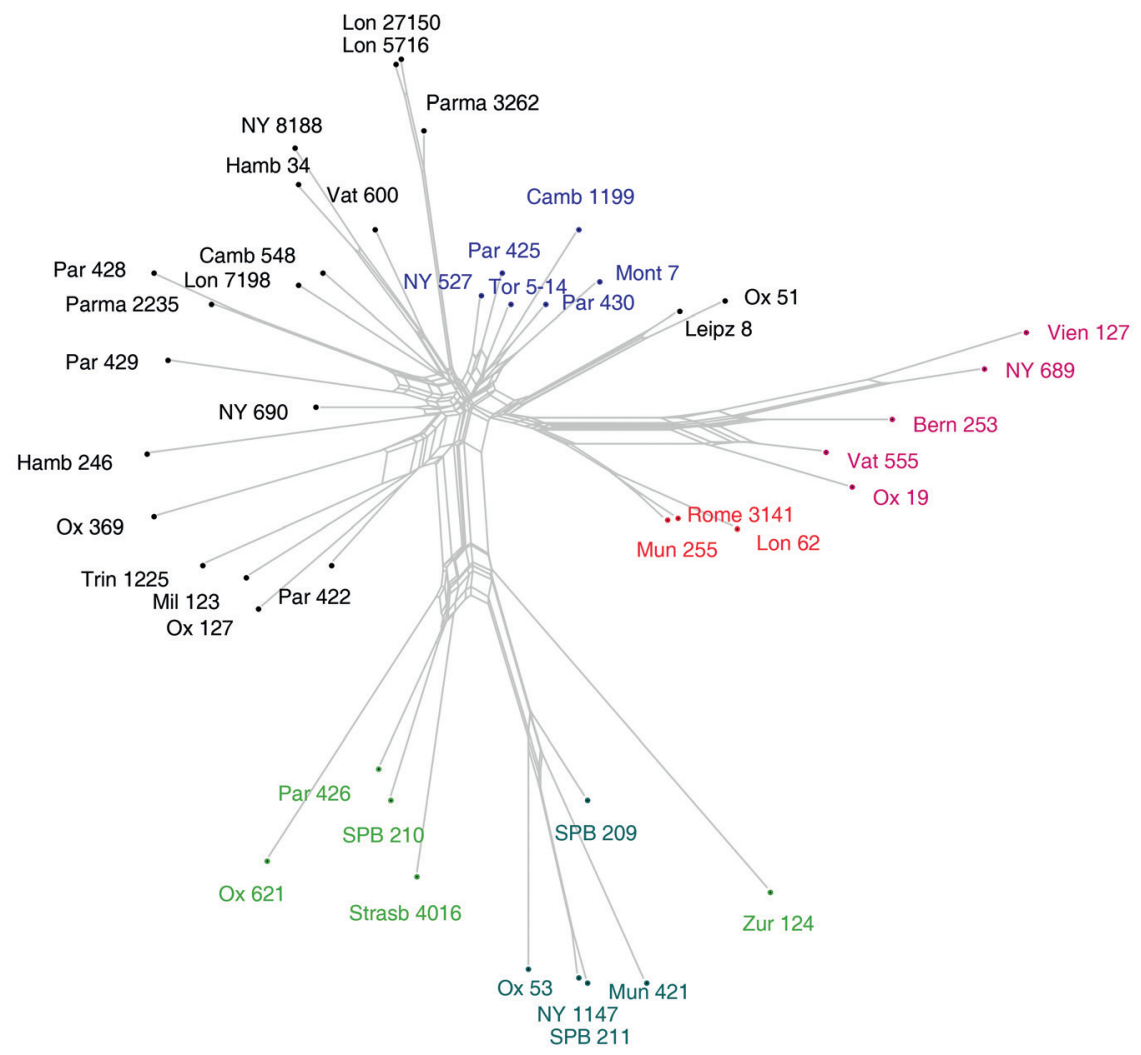

FIGURE 1 Clustering of manuscripts of TOH, chapter 428 obtained by NeighborNet. Bright red: cluster 1 (Sephardi-hand manuscripts of the original recension). Rose red: cluster 16 (Ashkenazi- and Italian-hand manuscripts of the original recension). Blue: cluster 2 (manuscripts of the extended recension). Green: cluster $3 a$, teal: cluster $3 b$ (Ashkenazi and Italian manuscripts with a revised calendar section, based on the extended recension)

Cluster 1 (colour-coded in shades of red) corresponds to what has been identified as the original recension of тон. ${ }^{11}$ It is composed of two sub-clusters: cluster a (bright red) consists of Sephardi-hand manuscripts, most probably copied on the Iberian peninsula; cluster $\mathrm{lb}$ (rose red) consists of Ashkenaziand Italian-hand manuscripts. Differences between these sub-clusters are demonstrated by Examples 1.1, 1.2, and 1.4 below. Three cluster $1 \mathrm{~b}$ manuscripts, Bern 253 (15th century, Ashkenazi), Vat 555 (1435, Italian) and Vien 127 (1436,

11 Galinsky, 'The Four Turim,' 312. 
Ashkenazi), contain an identical calendar for 1332/3-1503/4, 19-year cycles 269-277. ${ }^{12}$ This table differs from the calendar described by Jacob ben Asher in the prose text and is specific to cluster 1 b. Its starting point in 19-year cycle 269 , 1332/3-1350/1, probably reflects the time when the table was introduced into the transmission of тон, indicating that the Ashkenazi/Italian cluster $\mathrm{b} b$ was in existence by the final years of this period at the latest.

Cluster 2 (colour-coded blue) is made up of Sephardi-, Ashkenazi-, and Byzantine-hand manuscripts. Manuscript Par 425 found in this cluster has been listed by Galinsky among the best surviving representatives of the extended recension of тон. ${ }^{13}$ The extended recension is characterized by clearer, less ambiguous readings, and this comes through in our passage (see Examples 1.3 and 1.4). Readings in chapter 428 suggest that the extended recension is closer to Sephardi manuscripts of the original recension (cluster 1a) than to its Ashkenazi and Italian manuscripts (cluster 1b) (Examples 1.2, 1.4). A terminus ante quem for the publication of this recension is supplied by NY 527, which was copied in 1380 and is the earliest dated fragment of тон, but an earlier dating can be suggested on the basis of cluster 3 (see below).

Cluster 3, with its sub-clusters $3 \mathrm{a}$ (green) and $3 \mathrm{~b}$ (teal) includes manuscripts copied in Ashkenazi and Italian hands as well as a Sephardi-hand manuscript copied in Italy (for differences between the sub-clusters see Examples 1.2, 1.6). ${ }^{14}$ Cluster 3 builds on cluster 2 (Examples 1.1. 1.3, 1.4, 1.7) and has a set of readings not attested in other manuscripts (Examples 1.5, 1.9). Manuscripts in cluster 3 have an important feature in common: in them the chapter on the calculation of the astronomical new moon (Heb. molad) and equinoxes and solstices (Heb. tequfot $)^{15}$ is reworded and significantly expanded, providing sample calculations and reasons for various calendar rules. ${ }^{16}$ The sample calculations always refer to year 5108 (1347/8) and, unless this example is random, 1347/8 must be the year when the treatise on calendar reckoning was expanded in cluster 3

12 In the Jewish calendar years are divided into 19-year cycles of intercalation, numbered from Creation: cycle 1 stands for years 1-19 AM, cycle 2 for years 20-38 AM, and so on. For a detailed explanation of the workings of the Jewish calendar see R. Sar-Shalom, Gates to the Hebrew Calendar (Hebrew) (Netanyah 1984).

13 Galinsky, 'The Four Turim,' 312.

14 Camb 656, copied in Italy in a Sephardi hand, contains only the second half of the prose description of tables in тон, chapter 428 . Although it can be attributed to cluster 3a on the basis of the included text, for computational reasons it is not included in the NeighborNet graph in Fig. 1.

15 Chapter 427 in most printed editions.

16 First described by Galinsky, 'The Four Turim,' 337. 
manuscripts. This intimates that cluster 3 split off around this date and that cluster 2, on which cluster 3 is based, had been in existence before that.

That clusters $1 \mathrm{~b}$ and 3 , constituted by manuscripts copied in Ashkenazi and Italian hands, allude to $133^{-1350 / 1}$ and $1347 / 8$ respectively suggests that тOH spread out of its native Spain at a very early date, close to its composition time c. $1330 .{ }^{17}$ This dating is supported by other evidence that 'Arba'ah Turim was known in Italy and Ashkenaz already in the 14th century. A French rite siddur copied in Northern Italy in 1395 cites 'Arba'ah Turim in its halakhic marginal glosses. ${ }^{18}$ A late 14th-century Ashkenazi sage Shalom ben Isaac Neustadt knew 'Arba'ah Turim but was unimpressed with it, whereas his pupil Jacob ben Moses Levi Moelin (1365-1427) studied it extensively and testified to its popularity among Ashkenazi Jews. ${ }^{19}$

\section{Examples of Textual Variants}

Example 1.1

cluster $1 \mathrm{a}$

כמניין שני המחזורים

cluster $1 \mathrm{~b}$

cluster 2 , cluster 3 (a and b)

כמניין שנים של מחזור שמיו

כמניין שני המחזור

Example 1.2

clusters 1a, 2, 3a

cluster $1 \mathrm{~b}$

וגם ידע

cluster $3 b$

וגם צִריך לידע יוגע

וגם יודע

Example 1.3

cluster 1 ( $a$ and $b$ )

ותחת כל מחזור כמה מונים לבריאת עולם

clusters 2 and 3 ( $a$ and $b$ )

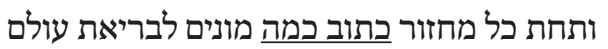

17 Galinsky, 'The Four Turim,' 309 n. 4.

18 Y.D. Galinsky, “"And this Scholar Achieved More than Everyone for All Studied from His Works": On the Circulation of Jacob b. Asher's Four Turim from the Time of Its Composition until the End of the Fifteenth Century' (Hebrew), Sidra 19 (2004) 25-45, esp. 38-39.

19 Galinsky, 'The Four Turim,' 292-293 and 293 n. 6. 
Example 1.4

cluster 1a

cluster $1 \mathrm{~b}$

cluster 2

cluster $3(\mathrm{a}$ and $\mathrm{b})$

Example 1.5

clusters 1 ( $a$ and $b), 2$

cluster 3 (a and b)

Example 1.6

clusters 1 ( $\mathrm{a}$ and b), $3 \mathrm{~b}$

cluster 2

cluster $3 a$

\section{Example 1.7}

clusters 1 ( $\mathrm{a}$ and $\mathrm{b}$ )

clusters 2, 3 (a and b)

\section{Example 1.8}

clusters 1a, 2

clusters $1 \mathrm{~b}, 3$ (a and b)

Example 1.9

clusters 1 ( $\mathrm{a}$ and $\mathrm{b}), 2$

cluster 3 ( $\mathrm{a}$ and $\mathrm{b}$ )

\section{בתוך יט מלפניו \\ בתוך יنט לפניו יט פלפניו \\ בתוך יنט שנה מלפני לפניון \\ בתוך יט שנים שלפניו}

הסימן של שנתו

סימן שנתו

ובמקום שיכלה מניינו

ובמקום שכלה מניינו

ובמקום שיצא מניינו

מצינו

מצאנו

צריד שידע

צריד לידע

עד תשלום ששת אלפים שנה

עד תשלום תקלָ שנה ששת אלפה

\section{Analysis of the Printed Corpus}

Let us now turn to chapter 428 in printed editions of тон published in the $15^{\text {th }}$ and 16 th centuries. ${ }^{20}$ As is shown in Fig. 2 , most incunabula editions apart

20 Twenty-one editions of тон are considered in this survey, some included in the full 'Arba'ah Turim, others limited to тон only (see Appendix 1). A small number of editions are excluded: in Naples 1492 (Joshua Soncino) the calendar section has not survived in the only publicly accessible copy (see n. 23); the small format edition published by Vincenzo Conti in Cremona in 1558 is identical with his larger format edition published in the same year, which latter is included in the survey; Riva di Trento 1561 (printing shop of Antonio Broën) is identical with Riva 1560 (Joseph Ottolenghi) apart from the title page where the 


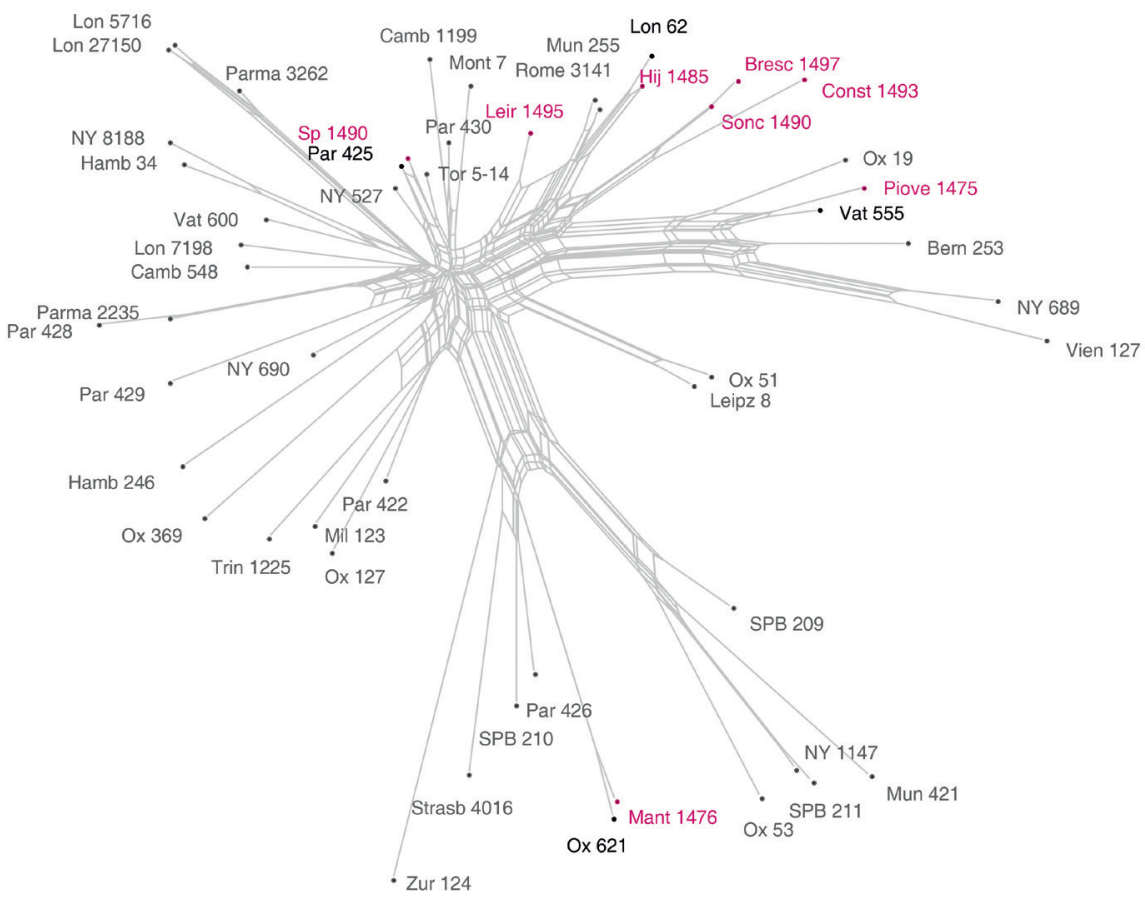

FIGURE 2 Clustering of incunabula imprints of TOH, chapter 428 obtained by NeighborNet. Rose red: incunabula. Black: manuscripts most closely related to the incunabula

from Sonc 1490, Bresc 1497 and Const 1493 are independent from one another, represent different manuscript clusters and are closest with manuscripts copied in the same geo-cultural areas as the imprints themselves.

1. Piove 1475 represents the Ashkenazi/Italian version of the original recension (cluster 1b) and is closest to Vat 555 (Italy, 1435/6).

2. Mant 1476 is very close to Ox 621 (Italy, 1494; cluster 3a) and reflects all its individual features. Ox 621 is later than the Mantua imprint but they clearly come from the same or very close exemplars not directly underlying any other surviving copy. Like Ox 621 and other manuscripts in cluster 3, Mant 1476 contains a revised version of the calendar section and is the only imprint to do so.

name and printer's device of Joseph Ottolenghi were deleted; Lublin 1599 (Kalonymus ben Mordecai Jaffe) does not contain the relevant chapter. For references on printing 'Arba'ah Turim see n. 5 . 
3. Hij 1485 represents a Sephardi version of the original short recension of тон (cluster 1a) and is closest with Lon 62 (15th century, Sepharad). Leir 1495 is also closely related to the Sephardi short recension and perhaps to the Hijar imprint itself, although it shows minor influence of the extended recension. In addition to their overall textual similarity, Lon 62, Hij 1485 and Leir 1495 share a closing formula תמו הלכות ראש חדש וקבועו תהילה לאל עונה אביון משועו (or מציל אביון in Leir 1495). This closing formula,

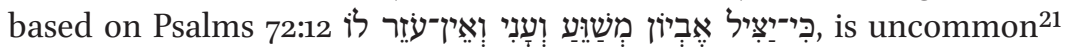
and confirms the connection between the manuscript and the imprints.

4. Sp 1490 is very closely associated with Par 425 (15th century, Sepharad), a flagman manuscript for the extended recension (cluster 2).

5. Sonc 1490 is not a straightforward representation of any particular manuscript or manuscript sub-group. It is clearly based on multiple exemplars of the short, original recension and moves freely between cluster 1a and cluster $\mathrm{ib}$ readings (it follows cluster 1 in all examples given above, siding with cluster 1a in Examples 1.1 and 1.8 and cluster 1b in Examples 1.2 and 1.4). Importantly, it exhibits textual variants which are not attested in any surviving manuscripts. Among the most conspicuous cases are:

\section{Example 2.1}

The phrase וכל שורה יنט קביעות; reworded to וכל קביעות שורה;

\section{Example 2.2}

The phrase וימנה בלוח הראשון מראש המחזור ההוא בשורה של מניין שני המחזור is printed with two deviations unattested in the manuscript tradition. It reads ממנה בלוח הראשון מראש המחזור ההוא בשורה של מנין שתי המחזורים.

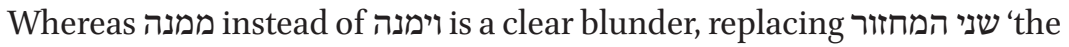
years of the cycle' with שתי המחזורים 'the two cycles' is a failed reinterpretation of the text;

Example 2.3

In the phrase יעיין בלוח הראשון תחת איזה מחזור ימצא מנין הסמוך למנינו the 3m.sg. verb ימצא is replaced with a $2 \mathrm{~m}$.sg. form that does not fit other

21 This formula could not be found in other manuscripts recorded in the SfarData database (http://sfardata.nli.org.il/). On scribes' closing formulas see M. Beit Arié, Hebrew Codicology. Historical and Comparative Typology of Medieval Hebrew Codices Based on the Documentation of the Extant Dated Manuscripts until 1540 from a Quantitative Approach, Pre-publication internet version 0.5 (2015) 143-147. 
verbs in the passage, all of which are in 3m.sg.:מין בלוח הראשון תחת איזה משור מחזור תמצא מנין הסמוך למנינו.

6. The last two incunabula of тон, Const 1493 and Bresc 1497, closely follow Sonc 149o's readings, including the above-mentioned mistakes and reinterpretations not attested in the manuscripts, and appear to have used it as their base text. Whereas Sonc 1490 and Bresc 1497 were printed in Italy by members of the same family, Solomon and Gershom Soncino respectively, the quick transit of the Soncino text from Italy to Constantinople may appear more surprising but can be explained. Const 1493 was printed by the brothers David and Samuel ibn Nahmias, Sephardi printers who fled to Constantinople. They seem to have travelled via Naples in 1492, where they stocked on North Italian paper and came into possession of semi-cursive types previously used in Joshua Soncino's printing shop in this city - supplies which they used to print their 'Arba'ah Turim. ${ }^{22}$ They could have obtained a copy of Sonc 1490 at the same time. ${ }^{23}$

If we now look at editions of тон printed in the 16th century, it becomes clear that all of them are based on incunabula imprints rather than manuscripts (see Fig. 3 below). Moreover, only one 16th-century imprint does not exhibit influence of the Soncino's text. Sal 1530 is directly based on Mant 1476 and repeats all of its readings and mistakes, both those that are shared with $\mathrm{Ox} 621$ and those that are not. All other 16th-century imprints of тон are to a greater or lesser extent Soncino-based. Fano 1516 by Gershom Soncino and Const 1540 by his son Eliezer Soncino follow Sonc 1490 with minor variations. All editions printed in Venice $(1522,1550,1563,1566,1589)$ closely represent the text as it was developed by the Soncinos with its peculiarities exemplified above.

Editions published in Central Europe are in a less straightforward relationship with the Soncino editions and may be seen as cousins. Crac 1538 has some of the readings found in Soncino imprints, although clear typos are weeded out (such as ממנה instead of וימנה in Example 2.2 above). It shows influence of Ashkenazi manuscripts like Hamb 34 and NY 8188 and occasionally lumps together Soncino variants with those in the manuscripts. Thus, the Soncino

22 Offenberg, 'The Printing History,' 224-225, 229.

23 Unfortunately, it is not possible to establish how Const 1493 relates to Joshua Soncino's edition of тон printed in Naples in 1492: only one copy of this edition survives in a public institution and in this copy the entire calendar section has been lost (Gesamtkatalog der Wiegendrücke (online), number M1040610, accessed December 1, 2016). 


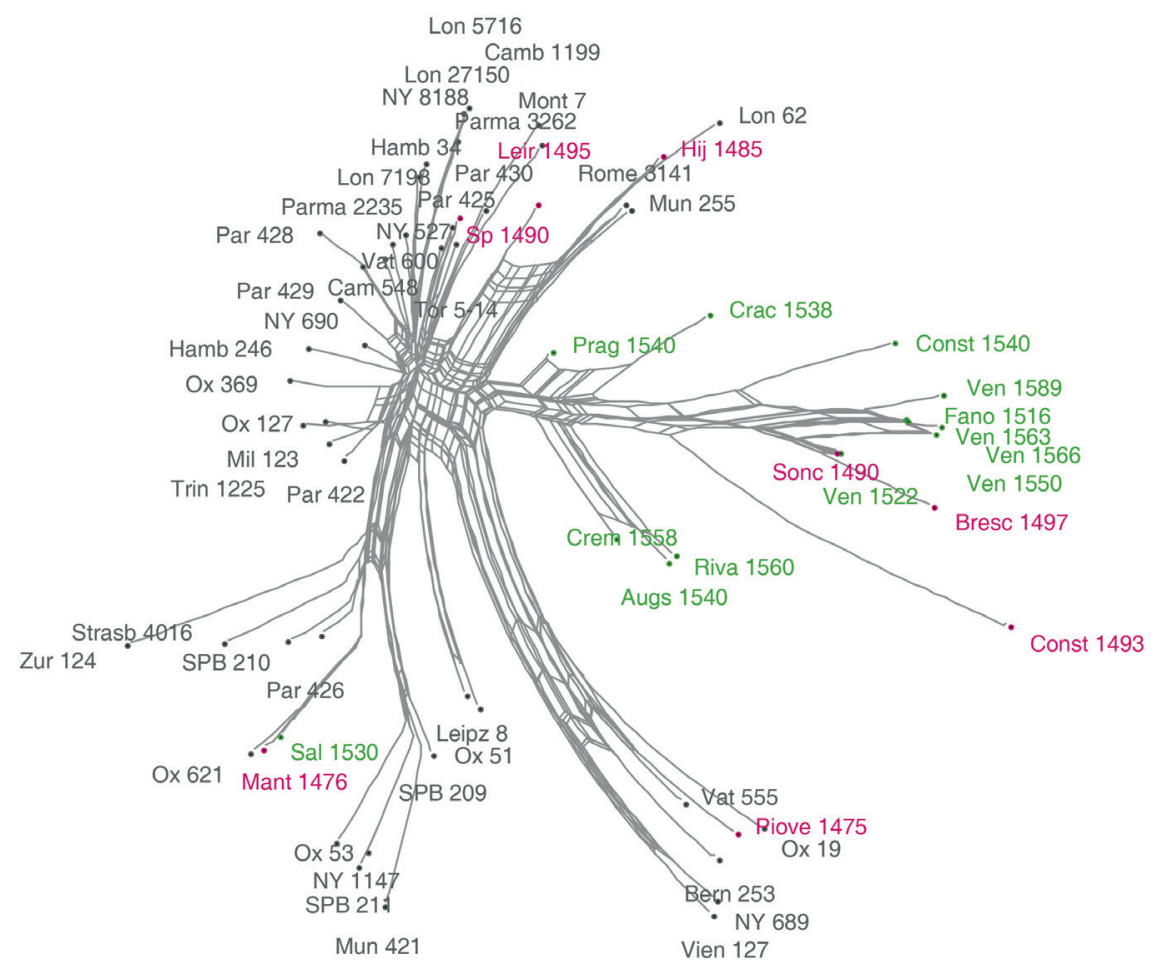

FIGURE 3 Clustering of 15 th-and 16 th-centuries imprints of TOH, chapter 428 obtained by NeighborNet. Rose red: incunabula. Green: 16th-century imprints. 'Magnifier'feature was applied to the region of 16 th-century imprints for increased readability

text reads ותחת כל מחזור כמה מונין לבריאת עולם בתחלתו. In Hamb 34 and NY 8188

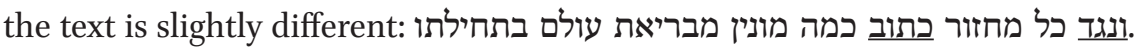
The more explicit reading כתוב כמה מונין instead of כמה מונין מונין is found in manuscripts and prints influenced by the extended recension, including Hamb 34 and NY 8188 (see Example 1.3). The variant is specific to Hamb 34 and NY 8188. In Crac 1538 we read ונגד ותחת כל מחזו" כתוב כמה מוני" לבריאת עולם בתחלתו,

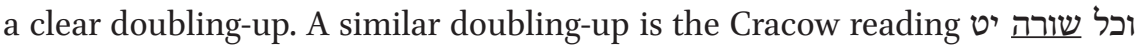
(כול with the Soncino's וכל יט קביעות שורה (Example 2.1).

Prag 1540, with the glosses and longer commentary by Abraham ben Avigdor, at the time the chief rabbi of Prague and the editor of the imprint, is the least certain case. This edition shows none of the Soncino's readings that are not found in the manuscript tradition. However, it does not follow any particular group of manuscripts and in many cases where manuscripts present a variety of readings makes the same choices as the Soncino texts (e.g., it 
differs from Sonc 1490 in the above Examples 1.1 and 1.3 only, where it follows the less ambiguous readings of clusters 2 and 3 ). Although it cannot be totally excluded that this imprint is independent and based on a selection of manuscripts, mainly of the short recension, it appears more likely that Prag 1540 is a Soncino-based edition collated with extended recension manuscripts. This conjecture is corroborated by a fragment of Sonc 1490 with hand-written (and potentially autograph) glosses by Abraham ben Avigdor, where some words and a chapter number have been crossed out and substituted by alternative readings, which latter appear in Prag $1540 .{ }^{24}$ A similar proofreading of Sonc 1490 may have led to the shaping of chapter 428 as it is published in Prag $1540 .{ }^{25}$

Augs 1540, based on the text of 'Arba'ah Turim corrected and annotated by Abraham ben Avigdor, ${ }^{26}$ presents a similar picture but has a few more Soncino features compared to Prag 1540 (e.g., תמצא in Example 2.3). One doubled-up reading is attested: Soncino imprints follow Sephardi short recension manuscripts (cluster 1a) and read באיזה מחזור הוא וכמה הוא, whereas in most other

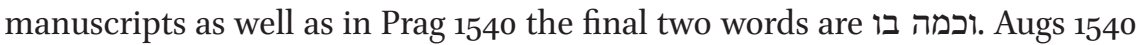
keeps both options and finishes וכמה בו הוא. The text in Crem 1558, and in Riva 1560 printed on its basis, closely follows Augs 1540. It has been known that Crem 1558 includes Abraham ben Avigdor's glosses according to the Augsburg edition. ${ }^{27}$ This study suggests that not only the glosses but its main text itself is based on Augs 1540.

The numeration of chapters in the imprints shows the same convergence towards a standard text. As mentioned above, chapter numbers are unstable and are not always present in manuscripts of тон. For example, chapter 428 is numbered 416 in Camb 1199, 428 in Lon 62, 438 in Par 430 and 445 in Vat 6oo. In early incunabula, this chapter has the same number as in their respective closest manuscripts: chapter 426 in Piove 1475 and Vat 555 (cluster 1b), chapter 421 in Mant 1476 and Ox 621 (cluster 3a), chapter 428 in Hij 1485, Leir 1495 and Lon 62 (cluster 1a), unnumbered in Sp 1490 and Par 425 (cluster 2). In Sonc 1490 the

24 This fragment was on sale at the Kedem Auction House on 11.03.2015. See www.kedem -auctions.com/he/node/18863, accessed December 1, 2016.

25 See also note 28 below.

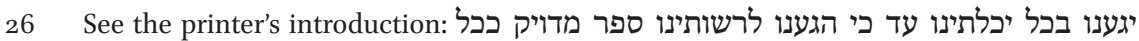
חפצינו מוגה בדקדוק רב מפי הרב מורינו ואלופינו ספינו הגאון מדון מהרר אברהם מפראג מאור דורינו ומתוכו הגהנו מלאכתינור דורינו.

27 On the relationship between Augs 1540, Const 1540, Crem 1558, and Riva 1560 see Bibliography of the Hebrew Book (online), numbers 136087, 178160, accessed December 14, 2016. 
chapter is numbered 428 , and this number is found in all subsequent imprints apart from Sal 1530 (chapter 421, as in Mant 1476) and Prag 1540 (chapter 427).28

\section{Supporting Considerations from Other Parts of тон}

Additional chapters of тон must be analysed in order to verify these conclusions. However, a number of observations external to the description of tables in chapter 428 indicate their validity. Firstly, the attribution of incunabula to underlying clusters of manuscripts revealed by this chapter fits exactly with that established earlier for Piove 1475, Hij 1485, and Sp 1490 on the basis of a macro-analysis of the corpus. ${ }^{29}$ Secondly, in describing the textual status of the Warsaw 1882 edition Galinsky demonstrates that this imprint deviates from the original recension of the work found in Sephardi manuscripts and carries modifications and additions associated with Ashkenazi and Italian copies. ${ }^{30}$ Galinsky gives seven supporting examples, from chapters 1, 30, 41, 214, 484, 486, and 694, and lists manuscript witnesses for each variant reading. The exact details of the readings are immaterial for the present argument; suffice it to say that all variants involve relatively large-scale changes beyond the level of single words or short phrases. No single manuscript checked by Galinsky contains all seven readings, indicating that they must have entered the print tradition through a variety of sources. A check of editions printed in the 15th and 16th centuries shows that in the period before 1490 Iberian imprints (Hij 1485, Sp 1490, and Leir 1495) do not include any of the variants, and Italian imprints are independent in their choice. Sonc 1490 includes four of the variants (in chapters 30, 41, 484, and 694), not attested together in any single examined manuscript, and is the first imprint to include variant readings in chapters 484 and 694. From then on, all imprints (apart from Sal 1530, which follows Mant 1476) include the four variants found in Sonc $1490 .{ }^{31}$ Prag 1540 adds the variant in chapter 214 and the earliest edition to have all seven non-original readings that I am currently aware of is Augs 1540. All seven variants are also found in

28 The chapter number 427 rather than 428 in Prag 1540 corroborates my hypothesis that this imprint is based on a copy of Sonc 1490 proofread by Abraham ben Avigdor. Indeed, in the Sonc 1490 copy with Abraham ben Avigdor's hand-written glosses, chapter number 169 is corrected to 168, corresponding to the reduction from 428 to 427 in Prag 1540. See https:// www.kedem-auctions.com/he/node/18863, accessed December 1, 2016.

29 Galinsky, 'The Four Turim,' 312.

$30 \quad$ Galinsky, 'The Four Turim,' 338-342.

31 I was unable to check this in Crac 1538. 
Crem 1558 and Riva 1560 . Here as in the description of tables, incunabula imprints before 1490 are independent, whereas all post-149o imprints apart from Sal 1530 follow the pattern set by Sonc 1490, with Central European imprints and Italian imprints that are based on them representing a further development within the Soncino's tradition.

\section{Conclusions}

Analysis of тон, chapter 428 in $15^{\text {th- }}$ and 16 th-centuries printed editions of тон suggests that the 1490 imprint by Solomon Soncino is a watershed in the history of printing тон. Before, imprints were independent and show close association with individual locally copied manuscripts. In 1490 Solomon Soncino created a text which was based on a variety of manuscript sources and does not directly reflect any particular group of manuscripts although it is closest to the original recension of тон. This imprint became the arche-

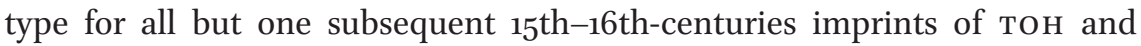
direct dependence on manuscripts subsided, albeit a cousin group of imprints from Central Europe and Italy may reflect a version of Sonc 1490 collated with extended recension manuscripts prevalent in Ashkenaz. A sporadic check of some later editions, such as Hanau 1610, Berlin 1702 and Warsaw 1861, attributes them to the Soncino family, with Hanau 1610 joining the Central European/ Italian cousin branch.

These results were obtained by a close textual investigation of one section of the book (part of chapter 428 in most printed editions). This section has not undergone a substantive revision in the manuscript tradition but features modifications on the level of single words and short phrases. As such it can be regarded as a model for тон printers' practices when dealing with the basic text of the work. Evidence from other passages, affected by larger-scale recensional changes, is in line with the presented findings. Further research is needed in order to verify and explain the influence exerted by Solomon Soncino's 1490 edition on the printed text of тон. 


\section{Appendix 1: Corpus of Manuscripts and Imprints}

\section{Manuscripts}

\begin{tabular}{lll}
\hline Siglum Classmark & Period & $\begin{array}{l}\text { Hand (and place of } \\
\text { copying if known to } \\
\text { be different) }\end{array}$ \\
\hline
\end{tabular}

\begin{tabular}{|c|c|c|c|}
\hline Bern 253 & $\begin{array}{l}\text { Bern, Burgerbibliothek, } \\
\text { Cod. } 253\end{array}$ & $15^{\text {th }}$ century & Ashkenazi \\
\hline Camb 1199 & Cambridge, UL, Add 1199.1 & 1432 & Byzantine \\
\hline Camb 548 & Cambridge, uL, Add 548 & $15^{\text {th }}$ century & Sephardi \\
\hline Camb 656 & Cambridge, uL, Add 656 & 1455 & $\begin{array}{l}\text { Sephardi } \\
\text { (in Italy) }\end{array}$ \\
\hline Hamb 246 & Hamburg, Stabi, Cod. hebr. 246 & 1463 & Ashkenazi \\
\hline Hamb 34 & Hamburg, Stabi, Cod. hebr. 34 & $14^{\text {th }}-15^{\text {th }}$ century & Ashkenazi \\
\hline Leipz 8 & Leipzig, UBL, B.H. fol. 8 & prob. before 1412 & Ashkenazi \\
\hline Lon $2715^{\circ}$ & London, B L, Add $2715^{\circ}$ & 1492 & Italian \\
\hline Lon 5716 & London, B L, Harley 5716 & 1475 & Sephardi (in Italy) \\
\hline Lon 62 & London, B L, Harley 62 & $15^{\text {th }}$ century & Sephardi \\
\hline Lon 7198 & London, B L, Harley 7198 & 1473 & Sephardi \\
\hline Mil 123 & $\begin{array}{l}\text { Milan, Biblioteca Ambrosiana, } \\
\text { X } 123 \text { Sup }\end{array}$ & c. 1479 & $\begin{array}{l}\text { Ashkenazi } \\
\text { (in Italy) }\end{array}$ \\
\hline Mont 7 & Montreal, Elberg, 7 & $14^{\text {th }}-15^{\text {th }}$ century & Sephardi \\
\hline Mun 255 & Munich, вsв, Cod. hebr. 255 & $15^{\text {th }}$ century & Sephardi \\
\hline Mun 421 & Munich, вsв, Cod. hebr. 421 & $14^{\text {th }}-15^{\text {th }}$ century & Ashkenazi \\
\hline NY 8188 & New York, JTs, 8188 & $15^{\text {th }}$ century & Ashkenazi \\
\hline NY 527 & New York, JTs, Rab 527 & 1380 & Sephardi \\
\hline NY 689 & New York, JTs, Rab 689 & 1437 & Ashkenazi \\
\hline NY 690 & New York, JTs, Rab 690 & $15^{\text {th }}$ century & Byzantine \\
\hline NY 1147 & New York, JTs, Rab 1147 & $145^{\circ}$ & Ashkenazi \\
\hline Ox 19 & Oxford, Bodl., Can. Or. 19 & 1475 & $\begin{array}{l}\text { Ashkenazi } \\
\text { (in Italy) }\end{array}$ \\
\hline Ox 127 & Oxford, Bodl., Mich. 127 & $15^{\text {th }}$ century & Ashkenazi \\
\hline Ox 369 & Oxford, Bodl., Mich 369 & 1444 & Ashkenazi \\
\hline Ox 621 & Oxford, Bodl., Mich 621 & 1494 & Italian \\
\hline Ox $5^{1}$ & Oxford, Bodl., Opp. $5^{1}$ & 1456 & Ashkenazi \\
\hline Ox 53 & Oxford, Bodl., Opp. 53 & $14^{\text {th }}-15^{\text {th }}$ century & Ashkenazi \\
\hline
\end{tabular}


Appendix 1 (cont.)

\begin{tabular}{|c|c|c|c|}
\hline Siglum & Classmark & Period & $\begin{array}{l}\text { Hand (and place of } \\
\text { copying if known to } \\
\text { be different) }\end{array}$ \\
\hline Par 422 & Paris, BNF, heb. 422 & 1487 & $\begin{array}{l}\text { Ashkenazi } \\
\text { (in Italy) }\end{array}$ \\
\hline Par 425 & Paris, BNF, heb. 425 & $15^{\text {th }}$ century & Sephardi \\
\hline Par 426 & Paris, BNF, heb. 426 & 1455 & $\begin{array}{l}\text { Ashkenazi } \\
\text { (in Italy) }\end{array}$ \\
\hline Par 428 & Paris, BNF, heb. 428 & 1476 & $\begin{array}{l}\text { Ashkenazi } \\
\text { (in Italy) }\end{array}$ \\
\hline Par 429 & Paris, BNF, heb. 429 & $15^{\text {th }}$ century & Ashkenazi \\
\hline Par 430 & Paris, BNF, heb. 430 & $15^{\text {th }}$ century & Ashkenazi \\
\hline Parma 2235 & $\begin{array}{l}\text { Parma, Biblioteca Palatina, } \\
\text { Cod. Parm. } 2235\end{array}$ & $15^{\text {th }}$ century & Ashkenazi \\
\hline Parma 3262 & $\begin{array}{l}\text { Parma, Biblioteca Palatina, } \\
\text { Cod. Parm. } 3262\end{array}$ & 1459 & Sephardi (in Italy) \\
\hline Rome 3141 & $\begin{array}{l}\text { Rome, Biblioteca Casanatense, } \\
3141\end{array}$ & $15^{\text {th }}$ century & Sephardi \\
\hline SPB 209 & St. Petersburg, RNL, Evr I 209 & 1419 & Ashkenazi \\
\hline SPB 210 & St. Petersburg, RNL, Evr I 210 & $14^{\text {th }}-15^{\text {th }}$ century & Ashkenazi \\
\hline $\operatorname{SPB} 211^{\mathrm{a}}$ & St. Petersburg, RNL, Evr I 211 & $\begin{array}{l}\text { c. } 1455 / 6 \text {, before } \\
1502\end{array}$ & Ashkenazi \\
\hline Strasb 4016 & Strasbourg, BNU, 4016 & $15^{\text {th }}$ century & Ashkenazi \\
\hline Tor $5^{-14}$ & $\begin{array}{l}\text { Toronto, University of Toronto, } \\
\text { Friedberg } 5^{-014}\end{array}$ & $14^{\text {th }}$ century? & Sephardi \\
\hline Trin 1225 & $\begin{array}{l}\text { Cambridge, Trinity College, } \\
\text { F } 1225\end{array}$ & 14 th century? & Ashkenazi \\
\hline Vat 555 & Vatican, BAV, Ross. 555 & 1435 & Italian \\
\hline Vat 600 & Vatican, BAV, Ross. 600 & $14^{\text {th }}-15^{\text {th }}$ century & Sephardi \\
\hline Vien 127 & Vienna, оNB, Cod. hebr. 127 & 1436 & Ashkenazi \\
\hline Zur 124 & $\begin{array}{l}\text { Zurich, Braginsky Collection, } \\
124\end{array}$ & c. 1446 & Ashkenazi \\
\hline
\end{tabular}

a SPB 211 is dated to the 18th century in the Merhav catalogue. This dating is clearly erroneous, as is shown both by the handwriting and by marks left by the main scribe and by a later user in the calendar table on fol. $54 \mathrm{v}$. The scribe marked out years $1455 / 6-1464 / 5$; the user - the 19-year cycle 277 , years $1484 / 5^{-1502 / 3}$. 


\section{Imprints}

Editions which include the full 'Arba'ah Turim:

\begin{tabular}{ll}
\hline Siglum & Imprint \\
\hline Piove 1475 & Piove di Sacco 1475 (Meshullam Cozy) \\
Sonc 1490 & Soncino 1490 (Solomon Soncino) \\
Const 1493 & Constantinople 1493 (David and Samuel ibn Nahmias) \\
Fano 1516 & Fano 1516 (Gershom Soncino) \\
Ven 1522 & Venice 1522 (Daniel Bomberg) \\
Sal 1530 & Salonika 1530 (Judah Gedaliya) \\
Augs 1540 & Augsburg 1540 (Hayyim Shahor) \\
Const 1540 & Constantinople 1540 (Eliezer Soncino) \\
Crem $155^{8}$ & Cremona $155^{8}$ (Vincenzo Conti), large edition \\
Riva 1560 & Riva di Trento 1560 (Joseph Ottolenghi) \\
\end{tabular}

Editions of тон only:

\begin{tabular}{ll}
\hline Siglum & Imprint \\
\hline Mant 1476 & Mantua 1476 (Abraham Conat) \\
Hij 1485 & Hijar 1485 (Eliezer Alantansi) \\
Sp 1490 & Spain (or Portugal) 1490 (printer unknown) \\
Leir 1495 & Leiria 1495 (Samuel d'Ortas) \\
Bresc 1497 & Brescia 1497 (Gershom Soncino) \\
Crac 1538 & Cracow 1538 (Johannis Halic) \\
Prag 1540 & Prague 1540 (Gershom ben Solomon ha-Kohen) \\
Ven 1550 & Venice 1550 (Marco Antonio Giustiniani) \\
Ven 1563 & Venice 1563 (Alviso Bragadin) \\
Ven 1566 & Venice 1566 (Giovanni Grypho) \\
Ven 1589 & Venice 1589 (Giovanni di Gara)
\end{tabular}




\section{Appendix 2: Clustering Textual Witnesses with NeighborNet}

NeighborNet ${ }^{32}$ is a computerised method for creating networks from data sequences. It is a data visualization tool, meaning that it does not attempt to reconstruct genealogical relations between objects of study but rather identifies and displays patterns in the data, separating objects into groups on the basis of shared traits. In text historical studies, the objects of study are copies of a text and their traits are textual variants found in different copies.

An important feature of the NeighborNet algorithm is that it does not assume data to be tree-like and divisible into clear-cut branches. It allows for contamination and hybridization of traits, directly incorporating it into the visual representation in the form of reticulation (box-like structures in Figs. 1, 2 and 3). If, however, data are treelike, the method produces a tree-like graph. Therefore, the shape of a graph gives an instant visual clue to the structure of the data. NeighborNet's ability to represent contamination is important for text historical analysis. It becomes particularly relevant when studying Jewish manuscripts, many of which were copied by scholar-scribes engaged in editorial work, including copying from multiple exemplars, re-interpreting and improving original readings, etc., all of which make it difficult to unambiguously assign manuscripts to families and establish relationships between copies. ${ }^{33}$ When some readings in a manuscript associate it with one group of copies and other readings - with another group of copies, NeighborNet does not ignore this conflict in the data (as an algorithm generating trees would) but indicates it by inter-connections among the branches.

32 NeighborNet is included in the SplitsTree4 package available from www.splitstree.org. For a discussion of NeighborNet among other methods of phylogenetic analysis, including mathematical and computations principles underlying these algorithms and examples of their application, see D.H. Huson and D. Bryant, 'Application of Phylogenetic Networks in Evolutionary Studies,' Molecular Biology and Evolution, 23/2 (2006) 254-267; D. Bryant and V. Moulton 'Neighbor-Net: An Agglomerative Method for the Construction of Phylogenetic Networks,' Molecular Biology and Evolution, 21/2 (2004) 255-265; D. Morrison, 'Networks in Phylogenetic Analysis: New Tools for Population Biology,' International Journal of Parasitology, 35 (2005) 567-582; D. Bryant, F. Filimon, and R. Gray, 'Untangling our past: Languages, Trees, Splits and Networks,' in R. Mace, C. Holden, and S. Shennan, eds., The Evolution of Cultural Diversity: Phylogenetic Approaches (London 2005) 69-85. On computer-aided stemmatics see T. Roos and T. Heikkilä, 'Evaluating Methods for Computer-Assisted Stemmatology Using Artificial Benchmark Data Sets,' Literary and Linguistic Computing 24/4 (2009) 417-433.

For references see footnote 10. 
A NeighborNet graph consists of nodes, branches, and boxes formed by sets of parallel edges. The outer nodes represent objects of study; the internal nodes cannot be interpreted as ancestors, but simply arise as a result of conflicts in the data. Branches and boxes represent partitions in the data (called 'splits' in phylogenetic terminology), with individual branches indicating uncontaminated tree-like data and boxes showing contamination. The length of a branch or of an edge of a box reflects the amount of traits that support this split. The dissimilarity between any two objects is measured as the shortest path along the branches and box edges of the graph that connects the corresponding nodes. The closer the nodes are on the graph, the more similar the objects.

To extract text historical information from a NeighborNet graph plotting copies of a particular text, one must look at the following aspects. Firstly, the shape of a graph indicates the level of contamination in the corpus, with more boxes meaning more complexity, and less clear division into families. Secondly, splits in the graph visualize how copies are divided into groups (e.g., red-, blue- and green-coded clusters in Fig. 1). Thirdly, the length of branches and parallel box edges is proportionate to the number of variant readings that distinguish a copy from its group members or a group of copies from the rest of the corpus. Thus, Fig. 1 shows that Mun 255 is closer to Rome 3141 than to Lon 62 (cluster 1a, red), and cluster 3 (shades of green) has more readings unattested in the rest of the corpus than cluster 2 (blue). Last but not least, it is important to remember that NeighborNet graphs do not represent genealogical relations, so that ancestors are placed at the same level with their descendants. Once clusters are identified, stemmatic relations within each cluster or between clusters can be studied by other methods. 